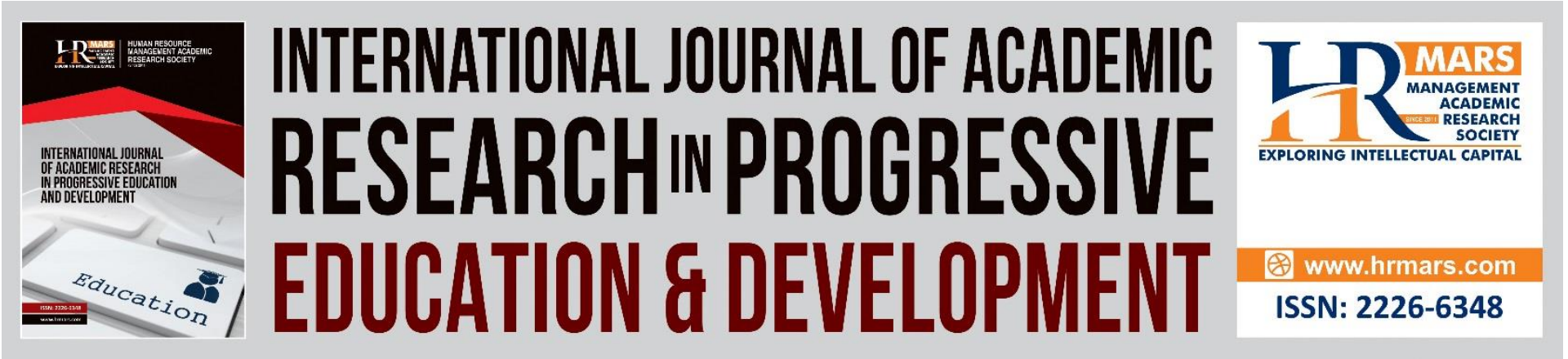

\title{
It Takes Two to Tango: Using TikTok Duet Challenge to Improve Conversation Skills
}

Ling Sue Zhen, Fatin Najiha Zainuddin, Masturah Aimuni Mohd Zin, Melor Md Yunus

To Link this Article: http://dx.doi.org/10.6007/IJARPED/v11-i1/12017

DOI:10.6007/IJARPED/v11-i1/12017

Received: 01 November 2021, Revised: 29 November 2021, Accepted: 16 December 2021

Published Online: 06 January 2022

In-Text Citation: (Zhen et al., 2022)

To Cite this Article: Zhen, L. S., Zainuddin, F. N., Zin, M. A. M., \& Yunus, M. M. (2022). It Takes Two to Tango: Using TikTok Duet Challenge to Improve Conversation Skills. International Journal of Academic Research in Progressive Education and Development, 11(1), 170-185.

Copyright: (C) 2022 The Author(s)

Published by Human Resource Management Academic Research Society (www.hrmars.com)

This article is published under the Creative Commons Attribution (CC BY 4.0) license. Anyone may reproduce, distribute, translate and create derivative works of this article (for both commercial and non-commercial purposes), subject to full attribution to the original publication and authors. The full terms of this license may be seen

at: http://creativecommons.org/licences/by/4.0/legalcode

Vol. 11(1) 2022, Pg. 170 - 185

http://hrmars.com/index.php/pages/detail/IJARPED

JOURNAL HOMEPAGE

Full Terms \& Conditions of access and use can be found at http://hrmars.com/index.php/pages/detail/publication-ethics 


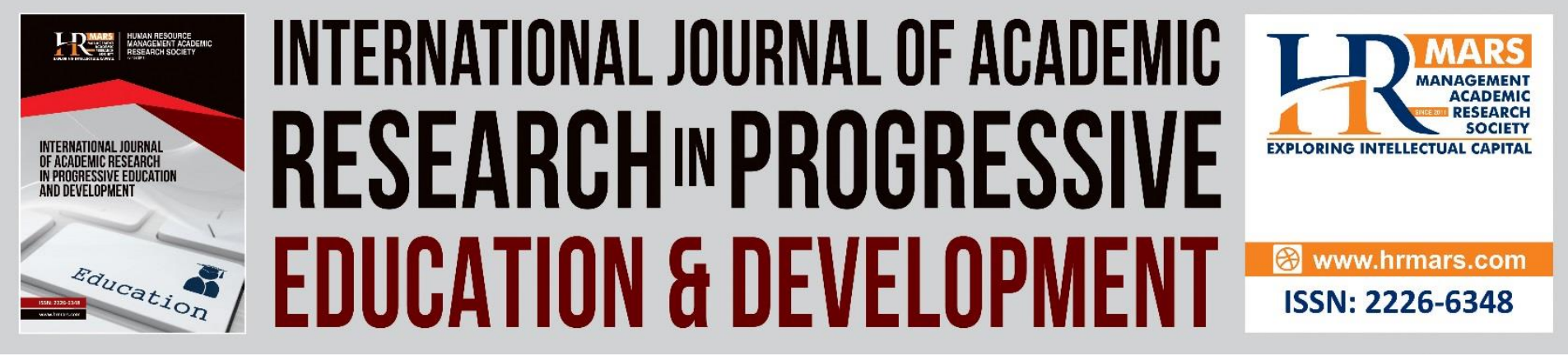

\title{
It Takes Two to Tango: Using TikTok Duet Challenge to Improve Conversation Skills
}

\author{
Ling Sue Zhen \\ SJK (C) Yuk Choi, Sabah, Malaysia \\ Email: p111781@siswa.ukm.edu.my \\ Fatin Najiha Zainuddin \\ SK Taman Midah, Kuala Lumpur, Malaysia \\ Email: p111924@siswa.ukm.edu.my \\ Masturah Aimuni Mohd Zin \\ SJK(T) Kuala Lipis, Pahang, Malaysia \\ Email: p112168@siswa.ukm.edu.my \\ Melor Md Yunus \\ Universiti Kebangsaan Malaysia, Bangi, Selangor, Malaysia \\ Email:melor@ukm.edu.my
}

\begin{abstract}
The short-video platform, TikTok is a popular social media platform in which it has exceeded Facebook as the most downloaded application internationally. It is worthy of comparison to other social media platforms such as Twitter, Twitch, Instagram and many more. Despite the fact that many relevant studies indicated the positive effects of employing social media in language learning and teaching, only an insubstantial amount of research was focused on the exploitation of TikTok for educational purposes in terms of language skills. On top of that, this also seems relatively appropriate to tackle the underlying issue of pupils losing the opportunity to engage in peer-to-peer conversations especially during English as a Second Language (ESL) lessons due to the Covid-19 pandemic restrictions. Hence, the researchers aimed to determine how Duet Challenge on TikTok could improve ESL learners' conversation skills. This study utilised a quasi-experimental research method to develop a learning activity through the manipulation of the Duet Challenge on TikTok and the data was gathered through pre-test and post-test. A total number of 30 primary school students in three different states participated in this study. The findings disclosed that there was an improvement in the pupils' conversation skills after participating in the Duet Challenge. Further research is encouraged to validate the findings of this study by involving more participants as well as actively incorporating the TikTok application in ESL learning. It is also hoped that this research will inspire teachers to explore the benefits of social media in the teaching and learning of English. Keywords: Tiktok, Social Media, Learning Tool, Conversation Skill
\end{abstract}




\section{Introduction}

Education used to be heavily associated with attending physical classes, in-person lectures and supervised learning environments. A common trend bounded by brick-and-mortar enclosures can be observed among these traditional methods. A new era of education has now appeared after undergoing severe alterations imposed by a major force of change, the digital age. The introduction of Information Technology (IT) and the Internet to the masses have transformed their perception towards the accessibility of education thus enabling the empowerment of their lives (Siau, 2018). Online learning did not only emphasize the possibility of acquiring new knowledge or enriching a possessed skill through numerous readily available sources but also eliminated the traditional boundary of physical learning sessions (Xie, Sau \& Nah, 2020). The nature of online learning itself is highly flexible, accessible, upholds equity, efficiency and emits global influence (Xie, Sau \& Nah, 2020) is increasingly attracting the participation of students and teachers alike. The uplift in online learning popularity has nonetheless attracted language teachers to establish the Mobileassisted Language Learning (MALL) method incorporating mobile technology such as smartphones and tablets in their teaching practice. Such an effective strategy integrating two of the most advanced technological innovations as a proxy to amplify the English language learning capabilities has proven to be rather successful (Hashim et. al., 2017).

Amidst the COVID-19 pandemic, even though online learning were strongly believed to be unaffected and strives predominantly due to an increase in demand to adapt (Li \& Lalani, 2020), a significant number of teachers and students struggled with adapting to the unfamiliar territory of fully online education under nationwide lockdown. Imposed restrictions on social gatherings have impacted not just adults but school children as well affecting their most needed language developing conversations only achievable through peer-to-peer interactions (Charney et al., 2021). Malaysia in particular is experiencing the same phenomena with lockdowns spanning over more than a year worth of school time. Students especially those at the Primary Level were deprived of their rights to hone their communication skills through these valuable interactions with English, commonly as the second language being affected more than ever. Consequently, a decline in English communication skills among primary school children has emerged due to this situation.

Referring to this issue at hand, the researchers of this paper were stipulated to revamp their teaching methods to adapt to the current pandemic restriction utilizing the most accessible piece of technology on top of being extremely popular among youngsters, social media specifically TikTok mobile application (Xiuwen \& Razali, 2021). TikTok has recently paved its way through the education world as a very effective yet entertaining language learning tool in this technology-driven era and surprisingly remained significantly valid in times of pandemic (Xiuwen \& Razali, 2021). Through the TikTok platform, knowledge is no longer exclusive content tailored to any specific group of people but is now made affordable, convenient and flexible through instantaneous and reliable worldwide sharing. The themes of equity and sustainability in education brought forth through this learning innovation have triggered a phenomenon across the world that promotes a better learning environment in all levels of education which is also in line with the Sustainable Development Goal 4 (SDG 4) which aspires to provide nondiscriminatory access and equal opportunities to education for all (United Nations, 2020)

Subsequently, the researchers have integrated the TikTok application particularly the currently trending Duet Challenge in primary school English-speaking lessons to determine whether previous claims regarding the effectiveness of social media in language learning hold. 
DEVELOPMENT

Vol. 11, No. 1, 2022, E-ISSN: 2226-6348 @ 2022 HRMARS

The intervention was made to experiment on whether this method could improve English as a Second Language (ESL) learners' conversation skills.

\section{Literature Review}

\section{Mobile-Assisted Language Learning (MALL)}

MALL encourages language learners to use mobile technologies to study a new language. The mobility of today's learners offers an extraordinary learning environment both in and out of the classroom. It is not always necessary for students to learn languages just within their school setting but they could learn it whenever and wherever they want by using their mobile devices. This is agreed by Geddes (2004) whereby he stated that mobile-assisted learning is typically identified by its ability to be accessed "anywhere, at any time". Since the world has entered the era of globalisation and industrialised countries are in fierce competition to develop and apply new technology, introducing mobile technology into the field of education is one of the most effective ways of mastering this globalisation (Ketut Sudarsana et al., 2019). Keegan (2003) also viewed that mobile-assisted learning is the new frontier in education and in the meantime, Azar and Nasiri (2004) agreed that this learning is typically focused on the most modern technologies. Kacetl and Klimova (2019) investigated the use of mobile applications in language instruction and they stated that mobile-assisted language learning has been developed as a viable tool to enhance language acquisition due to its various benefits. Thus, by taking learning and teaching outside the classroom walls, mobile technologies, specifically mobile-assisted language learning, allows students to dig deeper into what they're studying and allow them to start practicing the language at their own tempo and autonomously (Kuimova et.al., 2018).

Currently, learning English is viewed as a critical component of professional development and is considered as a criterion for being educated. Hence, providing a more convenient environment for students to study English is well-considered as one of the strategic educational aims for boosting student accomplishment and facilitating differentiation of learning requirements (Miangah \& Nezarat, 2012). Moreover, according to Wong et.al., (2016), English language teachers should provide an authentic learning environment for students to acquire and utilise the language in a real-life setting and it is vital for pupils to have a platform to implement their formal learning in the classroom. In this scenario, using the social networking sites (SNS) that are made available in mobile technologies enable students to discover a variety of online language learning resources and allows them to collaborate with their friends while learning to develop their own content (Shadiev, Hwang and Liu, 2018).

\section{Vygotsky's Cognitive Development Theory}

Vygotsky (1978) had pointed out that there are two degrees of development. The first level is the genuine level of development in which children are capable of solving difficulties on their own and the second one is the potential level of development when children are capable of solving complications with the help of adults or in collaboration with more competent friends. By referring to the second degree of development, this theory asserted that the children's development could be socially constructed with the guidance from others. As such, in the general context of learning, while getting assistance from others, interaction and communication are believed to happen. Moreover, Vygotsky (1978) had emphasized that for learning to take place, students must be exposed to tasks that require support from others. Hence, by assisting them, this theory proclaimed that the students will be able to master 
spoken skill as well as the language structure for reacting to specific social circumstances and initiating conversation with others. The interaction of a person with society, according to Lev Vygotsky, is part of cognitive development (Wang, 2009). Social interaction and contextualised communication were able to assist students in effectively learning English as cited by Tharp and Gallimore (1988); Vgotsky (1978) in Short (2017). Therefore, the use of the TikTok duet challenge as the medium to help students practice their conversation skills in English could possibly be linked with the cognitive development proposed by Vygotsky.

\section{ESL Learning and Social Media}

Educators in English as a Second Language (ESL) initiated to study the usage of online resources and tools, such as social media to encourage ESL students to practise their language outside of the classroom (Lee, 2020). According to a study by Yemer (2021), the language learning through social media platforms was able to improve ESL learners' comprehension on how to use English skills inside and outside the classroom besides allowing students to engage in both receptive and productive language learning (Rahmawati et.al., 2019). According to Rahmawati et.al (2019), speaking practices, such as conversing with or communicating to particularly English users on a few social networking sites such as Facebook, Instagram, Twitter, Telegram and Whatsapp have an impact on students' fluency, pronunciation, understanding, vocabulary, and grammar. Additionally, Ahmed (2019) discovered that the mobile application named WhatsApp was a good social networking tool for ESL learners to practice their language skills. Whatsapp application that is mainly used through smart mobile devices independent of formal classroom context shown to be beneficial to ESL students in this study. A study by Akkara et al (2020) on the usage of Whatsapp application also stated that it helped ESL learners in finding speaking partners to improve their oral skills in English. Looking at another social media platform that has helped English learners is a study conducted by Suthiwartnarueput \& Wasanasomsithi (2012). This study looked into the impact of using Facebook as a forum for low-intermediate Thailand EFL students to debate English grammar and writing in order to improve their English grammatical and writing skills. According to these researchers, using Facebook as a medium for interaction and grammatical debate helped students develop good attitudes about language learning and improved their English writing. Wongsa \& Son (2020) also conducted a study on the use of Facebook in enhancing Thai students' English-speaking skills. They had discovered that Facebook did have a positive influence on the students' speaking skills and their motivation towards learning English had increased. Furthermore, a study conducted by Handayani et al., (2018) on the usage of Instagram to improve ESL students' writing skills is considered as a useful and effective tool for enhancing students' writing abilities. According to other published research in this area, utilizing Instagram in language learning could enhance the students' writing skills (Nugroho \& Rahmawati, 2020). Therefore, it is plausible to proclaim that social media has numerous favourable benefits on ESL learning. The following section of this paper focuses on TikTok, a prominent social media application at the moment.

\section{TikTok in ESL Learning}

TikTok is considered the most used social media application with an overwhelming amount of popularity among the younger generation aged 30 and below ( $\mathrm{Wu}, 2020)$. Dai and Chen (2019) also reported that there was an increase in young people utilising TikTok. As such, TikTok was reviewed for ESL learning purposes on account of the frequency of using TikTok by these youngsters. Numerous published studies have opined that the usage of TikTok can 
DEVELOPMENT

Vol. 11, No. 1, 2022, E-ISSN: 2226-6348 @ 2022 HRMARS

help improve and increase ESL learners' English proficiency in terms of several language skills such as writing, reading and speaking.

According to Syaifuddin et al (2021), ESL learners showed a preference towards learning to write descriptive text with the help of TikTok videos. It was evident that TikTok was applied as an approach or means of ESL teaching and learning process. This was proven by another study conducted by Yunus et al (2019) through which it was implied that students who mentioned social media aids such as TikTok, Facebook, Instagram and many others were utilitarian in the teaching of ESL writing. Moreover, it was also revealed by another study carried out by Iswahyuni (2021) that the use of TikTok improves ESL writing, reading and speaking skills. With regards to the support of several studies in the usage of TikTok in learning English as a second language, Sherin and Dyer (2017) explained that the support of videos in learning was rather efficient in providing perceived experience in a language context among students. In other words, the videos in TikTok helped ESL learners to comprehend and process the contents easily. Thus, enhancing the English proficiency of ESL learners.

Similarly, ESL learning through experiences was emphasized by Hanim (2021). The researcher agreed with Sherin and Dyer (2017) in particular that the practice of introducing TikTok videos into contextual ESL learning improved English proficiency. This statement can be further explored by the study perpetrated by Koniah et al (2021). It was reported that students were actively participating in learning English just by watching TikTok videos as it increased their interest in learning with relatable content and context of language. In this respect, TikTok has begun to be a convenient tool to underpin ESL learning owing to its advantage to allow learners to practice English autonomously at their own pace. It was comparable to the findings of Kuimova et al (2018) of which media learning was a practical implementation in supporting language learning because of independent learning. Learners who have the chance to practice using English through TikTok were able to enrich or enhance their language skills. Ipan et al (2020) established that the social media challenge in TikTok enhanced ESL learners' capacity to converse in English. It was further concluded that ESL learners were able to elaborate more on the topics given in English, an essential technique in conversation skills, via video production in TikTok.

Corresponding to the enablement of ESL learning through experiences and contextual practice, TikTok also provided contextualised communication and social interactions to aid learners in mastering English constructively. As cited by Short (2017), real-life situations were imperative in ESL learning due to their nature of providing more opportunities for learners to practice and experience certain social expressions in English. Hence, TikTok is applicable in the process of ESL learning whereby it nurtures learners to have a functional English language which is common in social situations. Based on a study by Basit et al (2020), the findings demonstrated that there was evidence of enhanced English contextualised social expressions through TikTok. Besides, ESL learners learned to be fluent in using suitable or appropriate social expressions in relevant social situations with TikTok. In parallel, TikTok was described to be an effective influence of contextualised learning as it improved English vocabulary as learners found it easier to understand the language through speaking and listening (Fahdin, 2020). 
DEVELOPMENT

Vol. 11, No. 1, 2022, E-ISSN: 2226-6348 @ 2022 HRMARS

\section{Conversation Skills in ESL Learning}

As specified by Custer et al (2021), proficient conversation skills are significant in manifesting and perpetuating personal and social relationships. The conversations played a key role in making sure ESL learners develop the ability to correctly express socially to better understand situations, people and to be understood. In order to do so, ESL learners must have certain competence in conversations such as having a good command of vocabulary, pronunciation and grammar. This is later substantiated by the findings in a study by Hamad and Seyyedi (2020). The study mentioned that the majority of the learners faced difficulties in having English conversations because of linguistic factors linked to limited vocabulary and incorrect pronunciation. Therefore, multiple published studies have divulged the purport of focusing on communication, vocabulary, pronunciation and grammar to elevate ESL conversation skills (Priya \& Kumar, 2020; Wahyuningsih \& Afandi, 2020; Nuraeni, 2021; Sedliarova \& Soloveva, 2021).

Darmuki (2018) disclosed that there will be considerations for contemplation to develop and practice conversation skills in an ESL setting. Among those were the opportunities that should be given to learners so that they can present and practice real communication to achieve impeccable use of spoken English in conversations. Supplementary to this statement, Mezied (2021) emphasised that focusing on real communication will greatly develop learners' spontaneity in speaking and coping with conversation. However, Sedliarova and Soloveva (2021) preferred learning conversation skills by reproducing the conversation through imitations, predicting speech cliches and working on grammar patterns in a controlled or structured manner.

In contrast with practicing within the range of real language context and focusing on speech imitations, Nurullayevna (2020) highlighted the necessity for drilling correct pronunciations in English conversations. It was noted that the knowledge of vocabularies became useless if pronunciation mistakes resulted in serious misunderstandings but Atika et al (2020) beg to differ. The justification emphasized vocabulary memorization and grammatical comprehension which were more important in producing conversations. Regardless of the focus of communication, vocabulary, pronunciation and grammar in ESL conversation skills, ESL learners should learn conversation skills according to their learning objectives. In retrospect, some teachers might have wanted ESL learners to pay more attention to fluency instead of accuracy in their conversation skills (Tuyen, 2021). Consequently, rendering vocabulary, grammar and pronunciation obsolete.

\section{Methodology}

This study employed a quasi-experimental research design to determine whether the Duet Challenge on TikTok plays a role in improving ESL learners' conversation skills. This study involved thirty Year 6 primary school students from three different states of Kuala Lumpur, Pahang and Sabah. The researcher utilised a non-random sampling whereby only ten students with a low level of proficiency were selected from each school. They were chosen based on their overall performance in the English subject. The research instrument consists of a pretest and post-test by which the pupils have to role-play daily conversations in pairs. Five different situations encompassing happiness, concern, sorrow, giving encouragement and expressing opinions were structured based on the learning standard 1.2.1 that could be found in the Dokumen Standard Kurikulum dan Pentaksiran (DSKP). The tests were conducted to determine the level of the Year 6 students' conversation skills before and after the intervention was executed. In attaining a more precise set of data, a speaking evaluation 


\section{DEVELOPMENT}

Vol. 11, No. 1, 2022, E-ISSN: 2226-6348 @ 2022 HRMARS

checklist which is adapted from the Cambridge Key English Test was used as an instrument during the pre-test and the post-test. It comprises grammar and vocabulary, pronunciation as well as interactive communication aspect.

\section{Findings and Discussion}

This study has investigated the effectiveness of TikTok Duet Challenge in improving ESL learners' conversation skills. Table 1 showed the marks obtained by all 30 participants for the pre-test and post-test. Based on Table 1, there was an increment in the results of the participants' post-test. The marks showed improvement between the pre-test and post-test. It could be concluded that the TikTok Duet Challenge helped the participants to improve their conversation skills.

Table 1. Marks for pre-test and post-test

\begin{tabular}{|l|l|l|}
\hline Research Participant & Pre-Test Mark & Post-Test Mark \\
\hline $\begin{array}{l}\text { K1 } \\
\text { (Kuala Lumpur) }\end{array}$ & $8 / 15$ & $9 / 15$ \\
\hline K2 & $9 / 15$ & $11 / 15$ \\
\hline K3 & $9 / 15$ & $12 / 15$ \\
\hline K4 & $8 / 15$ & $10 / 15$ \\
\hline K5 & $9 / 15$ & $11 / 15$ \\
\hline K6 & $8 / 15$ & $11 / 15$ \\
\hline K7 & $9 / 15$ & $11 / 15$ \\
\hline K8 & $9 / 15$ & $11 / 15$ \\
\hline K9 & $8 / 15$ & $10 / 15$ \\
\hline K10 & $9 / 15$ & $11 / 15$ \\
\hline P1 & $9 / 15$ & $11 / 15$ \\
(Pahang) & & $11 / 15$ \\
\hline P2 & $9 / 15$ & $9 / 15$ \\
\hline P3 & $7 / 15$ & $10 / 15$ \\
\hline P4 & $8 / 15$ & $9 / 15$ \\
\hline P5 & $7 / 15$ & $12 / 15$ \\
\hline P6 & $9 / 15$ & $12 / 15$ \\
\hline P7 & $9 / 15$ & \\
\hline & & \\
\hline
\end{tabular}




\begin{tabular}{|l|l|l|}
\hline P8 & $8 / 15$ & $10 / 15$ \\
\hline P9 & $8 / 15$ & $10 / 15$ \\
\hline P10 & $7 / 15$ & $9 / 15$ \\
\hline $\begin{array}{l}\text { S1 } \\
\text { Sabah) }\end{array}$ & $7 / 15$ & $10 / 15$ \\
\hline S2 & $8 / 15$ & $10 / 15$ \\
\hline S3 & $7 / 15$ & $9 / 15$ \\
\hline S4 & $9 / 15$ & $10 / 15$ \\
\hline S5 & $9 / 15$ & $11 / 15$ \\
\hline S6 & $7 / 15$ & $9 / 15$ \\
\hline S7 & $9 / 15$ & $11 / 15$ \\
\hline S8 & $8 / 15$ & $10 / 15$ \\
\hline S9 & $8 / 15$ & $10 / 15$ \\
\hline S10 & $9 / 15$ & $11 / 15$ \\
\hline
\end{tabular}

Based on the analysis in Table 1, it could be interpreted that all 30 participants showed great progress in their conversation skills after engaging in the TikTok Duet Challenge. This proved that the intervention was a success. A similar finding to this study by Ipan et al. (2020) concluded that social media challenges in TikTok have the potential to improve ESL learners' ability to have an English conversation. Since ESL learners were allowed to experience relatable language context through the Duet Challenge, it is proven that it served as an integral factor of enhancing their conversation skills. Correspondingly, Vygotsky (1978) maintained the fact that learners should experience hands-on tasks for learning to occur. By way of explanation, TikTok Duet Challenge played a significant role in refining conversation skills due to its relatable and experiential nature in the process of learning.

A speaking evaluation checklist comprising grammar and vocabulary, pronunciation and interactive communication aspects was employed during the pre-test and the post-test. Table 2 showed the participants' marks/bands on grammar and vocabulary aspects. Their marks were analysed and in the pre-test, more than half of the participants, 16 participants $(53.3 \%)$ were at Band 2. They were in the middle of having minimal and moderate commands over grammatical forms. They were able to employ isolated words and phrases as their vocabulary list and used suitable vocabulary to talk about familiar contexts. However, after the intervention was carried out, during the post-test, 27 participants (90\%) were at Band 3. They had shown moderate commands over grammatical forms and had the ability to talk about familiar contexts using suitable vocabulary. They had shown a vast increment in the grammatical forms and vocabulary aspects. 
INTERNATIONAL JOURNAL OF ACADEMIC RESEARCH IN PROGRESSIVE EDUCATION AND

DEVELOPMENT

Vol. 11, No. 1, 2022, E-ISSN: 2226-6348 @ 2022 HRMARS

Table 2. A comparison of mark/band for Grammar and Vocabulary aspect in pre-test and posttest

\begin{tabular}{|c|c|c|c|}
\hline \multirow{2}{*}{$\begin{array}{l}\text { Mark/ } \\
\text { Band }\end{array}$} & \multirow[b]{2}{*}{$\begin{array}{l}\text { Description for Grammar and Vocabulary } \\
\text { aspect }\end{array}$} & \multicolumn{2}{|c|}{ Frequency/ Percentage (\%) } \\
\hline & & Pre-test & Post-test \\
\hline 1 & $\begin{array}{l}\text { Minimal commands over grammatical forms. } \\
\text { Isolated words and phrases are used as a } \\
\text { vocabulary. }\end{array}$ & $\begin{array}{l}0 \\
(0 \%)\end{array}$ & $\begin{array}{l}0 \\
(0 \%)\end{array}$ \\
\hline 2 & Intermediary between Bands 1 and 3 & $\begin{array}{l}16 \\
(53.3 \%)\end{array}$ & $\begin{array}{l}0 \\
(0 \%)\end{array}$ \\
\hline 3 & $\begin{array}{l}\text { Moderate commands over grammatical forms } \\
\text { Talks about familiar contexts using suitable } \\
\text { vocabulary. }\end{array}$ & $\begin{array}{l}14 \\
(46.7 \%)\end{array}$ & $\begin{array}{l}27 \\
(90 \%)\end{array}$ \\
\hline 4 & Intermediary between Bands 3 and 5 & $\begin{array}{l}0 \\
(0 \%)\end{array}$ & $\begin{array}{l}3 \\
(10 \%)\end{array}$ \\
\hline 5 & $\begin{array}{l}\text { Advanced commands over grammatical forms. } \\
\text { Employs a variety of vocabulary in daily } \\
\text { interactions. }\end{array}$ & $\begin{array}{l}0 \\
(0 \%)\end{array}$ & $\begin{array}{l}0 \\
(0 \%)\end{array}$ \\
\hline
\end{tabular}

Comparably, a different study carried out by Iswahyuni (2021) developed a congruous result to this research. According to the study, the usage of TikTok improved ESL speaking skills in terms of grammatical patterns and vocabulary. Undeniably, Grammar and Vocabulary are important components of a conversation skill. As mentioned by Hamad and Seyyedi (2020), linguistic factors can affect the capacity of a conversation skill. Moreover, Atika et al (2020) also drew special attention to vocabulary memorization and grammatical comprehension which were more important in producing conversations. Therefore, this intervention was capable of cultivating the aspects of grammar and vocabulary in the conversation skills of the 27 participants.

Table 3 showed the participants' marks/bands on pronunciation aspects. The pronunciation levels of the participants were analysed according to each band. In the pre-test, 28 participants (93.3\%) were at Band 3. Their pronunciation abilities were fairly comprehensible with minimal control of phonological features. However, after the intervention was carried out, only $18(60 \%)$ of them were still at Band 3 whereby the rest 12 participants (40\%) had improved to Band 4 where their pronunciation was in between of fairly comprehensible with minimal control of phonological features and very comprehensible and had some phonological control in both utterance and word level. Some of them had shown an improvement in their pronunciation ability. 
INTERNATIONAL JOURNAL OF ACADEMIC RESEARCH IN PROGRESSIVE EDUCATION AND

DEVELOPMENT

Vol. 11, No. 1, 2022, E-ISSN: 2226-6348 @ 2022 HRMARS

Table 3. A comparison of mark/band for Pronunciation aspect in pre-test and post-test

\begin{tabular}{|c|c|c|c|}
\hline \multirow[b]{2}{*}{$\begin{array}{l}\text { Mark/ } \\
\text { Band }\end{array}$} & \multirow[b]{2}{*}{ Description for Pronunciation } & \multicolumn{2}{|c|}{ Frequency/ Percentage (\%) } \\
\hline & & Pre-test & Post-test \\
\hline 1 & $\begin{array}{l}\text { Has poor phonological control and is frequently } \\
\text { incomprehensible. }\end{array}$ & $\begin{array}{l}0 \\
(0 \%)\end{array}$ & $\begin{array}{l}0 \\
(0 \%)\end{array}$ \\
\hline 2 & Intermediary between Bands 1 and 3 . & $\begin{array}{l}2 \\
(6.7 \%)\end{array}$ & $\begin{array}{l}0 \\
(0 \%)\end{array}$ \\
\hline 3 & $\begin{array}{l}\text { Fairly comprehensible with minimal control of } \\
\text { phonological features. }\end{array}$ & $\begin{array}{l}28 \\
(93.3 \%)\end{array}$ & $\begin{array}{l}18 \\
(60 \%)\end{array}$ \\
\hline 4 & Intermediary between Bands 3 and 5 . & $\begin{array}{l}0 \\
(0 \%)\end{array}$ & $\begin{array}{l}12 \\
(40 \%)\end{array}$ \\
\hline 5 & $\begin{array}{l}\text { Very comprehensible and has some } \\
\text { phonological control in both utterance and } \\
\text { word level. }\end{array}$ & $\begin{array}{l}0 \\
(0 \%)\end{array}$ & $\begin{array}{l}0 \\
(0 \%)\end{array}$ \\
\hline
\end{tabular}

Essentially, it was evident that this intervention provided participants with countless practices within the range of realistic language contexts. The participants were constantly exposed to the familiarity of using the appropriate pronunciation during actual conversations. As attested by Nurullayevna (2020), there was an immediate necessity for the drilling of correct English pronunciation for conversations. In this study, the constant exposure to realistic situations that applied the usage of certain social conversations improved the participants' conversation skills in terms of the aspect of pronunciation. As agreed by Hanim (2021), the method of utilising TikTok in contextual ESL lessons greatly elevated English proficiency.

Table 4 showed mark/band for the interactive communication aspect among the participants that had been analysed. During the pre-intervention, most of the participants, 26 participants $(86.7 \%)$ were at Band 3 . They were having minimal difficulty in maintaining simple conversation and additional assistance was required. However, during the post-test, they had shown improvement whereby 24 participants $(80 \%)$ of them were at Band 4 where they were in intermediary of having minimal difficulty in maintaining simple conversation and able to maintain simple conversation. Nevertheless, they were also in between needing additional assistance and minimal assistance. It could be concluded that their interactive communication aspect had improved. 
INTERNATIONAL JOURNAL OF ACADEMIC RESEARCH IN PROGRESSIVE EDUCATION AND

DEVELOPMENT

Vol. 11, No. 1, 2022, E-ISSN: 2226-6348 @ 2022 HRMARS

Table 4. A comparison of mark/band for Interactive Communication aspect in pre-test and post-test

\begin{tabular}{|c|c|c|c|}
\hline \multirow{2}{*}{$\begin{array}{l}\text { Mark/ } \\
\text { Band }\end{array}$} & \multirow[b]{2}{*}{ Description for Interactive Communication } & \multicolumn{2}{|c|}{ Frequency/ Percentage (\%) } \\
\hline & & Pre-test & Post-test \\
\hline 1 & $\begin{array}{l}\text { Difficult to maintain basic conversation. } \\
\text { Extensive assistance is required. }\end{array}$ & $\begin{array}{l}0 \\
(0 \%)\end{array}$ & $\begin{array}{l}0 \\
(0 \%)\end{array}$ \\
\hline 2 & Intermediary between Bands 1 and 3 . & $\begin{array}{l}4 \\
(13.3 \%)\end{array}$ & $\begin{array}{l}0 \\
(0 \%)\end{array}$ \\
\hline 3 & $\begin{array}{l}\text { Minimal difficulty in maintaining simple } \\
\text { conversation. Additional assistance is required. }\end{array}$ & $\begin{array}{l}26 \\
(86.7 \%)\end{array}$ & $\begin{array}{l}6 \\
(20 \%)\end{array}$ \\
\hline 4 & Intermediary between Bands 3 and 5 . & $\begin{array}{l}0 \\
(0 \%)\end{array}$ & $\begin{array}{l}24 \\
(80 \%)\end{array}$ \\
\hline 5 & $\begin{array}{l}\text { Able to maintain simple conversation. Requires } \\
\text { minimal assistance. }\end{array}$ & $\begin{array}{l}0 \\
(0 \%)\end{array}$ & $\begin{array}{l}0 \\
(0 \%)\end{array}$ \\
\hline
\end{tabular}

In terms of conversation skills, the propensity to communicate is partly responsible for a successful social exchange between ESL learners. The results derived from Table 4 already presented the intervention's accomplishment in advancing successful communication among the participants. Similarly, Mezied (2021) found that focusing on real communication enabled the development of conversation skills. Interestingly, there were some studies that focused more on fluency instead of communication (Tuyen, 2021). Regardless of the importance of vocabulary, grammar, pronunciation and communication in conversation skills, some believe that getting the meaning across during a conversation is more realistic.

\section{Conclusion}

Based on the findings of this study, most participants have shown improvement in their conversation skills after participating in the TikTok Duet Challenge intervention. The grammar, vocabulary, pronunciation, as well as interactive communication aspects, were well developed after the intervention. Indeed, the intervention utilised through TikTok clearly indicated that it could improve ESL learners' conversation skills as well as it could be employed as an effective interactive tool for teaching particular skills targeted in ESL.

This research also corroborates the current education that evolves toward a more learnercentered model and self-directed learning that are both crucial to develop independent learners. Teachers could utilize the intervention proposed or employ a variety of other mobile applications to create new learner-centered activities and transform the existing activities to foster collaborative learning. Besides, researchers agreed that this research definitely would give a meaningful impact on social skills even though pupils struggle to improve their socialization during the pandemic. Furthermore, the application of mobile technologies in teaching and learning, in general, and social media applications in particular continues to grow in recent years. The use of prominent social media is widely acknowledged to be 
pleasurable and beneficial to students' learning. Hence, it is prudent that teachers grab this opportunity to enhance their teaching and learning processes.

Further research is encouraged to validate the findings of this study by involving more participants as well as actively incorporating TikTok application in ESL learning. The TikTok Duet Challenge also could be extended by adding more social situations in various contexts. On top of that, this research could also be conducted at secondary and tertiary education levels and the skills that can be focused on are fluency and vocabulary for communicative purposes. Eventually, researchers agreed that proper instruction from teachers is required for students in all education levels in order to focus on the specific skills targeted despite the fact that the new generation is very well adapted to current social media. Overall, this research is significant to assist with teaching and learning especially during the time of the pandemic. The use of the TikTok application in improving conversation skills is hoped to inspire teachers to explore the benefits of social media in the teaching and learning of English.

\section{Corresponding Author}

Melor Md Yunus (PhD)

Department of Research and Innovation, Faculty of Education, Universiti Kebangsaan Malaysia, 43600 UKM, Bangi, Selangor, Selangor Darul Ehsan, Malaysia.

Email: melor@ukm.edu.my

\section{References}

Ahmed, S. T. S. (2019). Chat and learn: Effectiveness of using WhatsApp as a pedagogical tool to enhance EFL learners' reading and writing skills. International Journal of English Language and Literature Studies, 8(2), 61-68.

https://doi.org/10.18488/journal.23.2019.82.61.68

Akkara, S., Anumula, V., \& Mallampalli, M. (2020). Impact of WhatsApp interaction on improving L2 speaking skills. iJET, 15(3), 250-259.

Atika, S., Fitri, D. E., \& Surjono, H. D. (2020). The effectiveness of using QR-CODE to improve students' speaking skills and motivation. Proceedings of International Conference on The Future of Education (IConFEd), 234-241.

Azar, A. S., \& Nasiri, H. (2014). Learners' attitudes toward the effectiveness of mobile assisted language learning (MALL) in L2 listening comprehension. Procedia-Social and Behavioral Sciences, 98, 1836-1843.

Basit, S., Siang, W. E., Avelino, N. M., \& Yunus, M. M. (2020). Enhancing year 5 pupils' English speaking through the TIKLET module. Proceedings of International Conference on The Future of Education (IconFEd), 298-303.

Charney, S. A., Camarata, S. M., \& Chern, A. (2021). Potential impact of the COVID-19 pandemic on communication and language skills in children. Otolaryngology - Head and Neck Surgery (United States), 165(1), 1-2. https://doi.org/10.1177/0194599820978247

Custer, T. N., Stiehl, C. M., \& Lerman, D. C. (2021). Outcomes of a practical approach for improving conversation skills in adults with autism. Journal of Applied Behavior Analysis, 54, 309-333.

Dai, L., \& Chen, P. (2019). Reasons for the popularity of TikTok, the shortages, and the ways forward. Advances in Social Science, Education and Humanities Research, 346, 544548. 
DEVELOPMENT

Vol. 11, No. 1, 2022, E-ISSN: 2226-6348 @ 2022 HRMARS

Darmuki, A. (2018). The development and evaluation of speaking learning model by cooperative approach. International Journal of Instruction, 11(2), 115-128.

Dressman, M., \& Sadler, R. W. (2019). The handbook of informal language learning. The Handbook of Informal Language Learning. Wiley. https://doi.org/10.1002/9781119472384

Diana, A. I. W. K., Blaise, C. C., \& Yunus, M. M. (2020). Enhancing form 4 pupils' speaking skills via TikTok. Changing Lives in Brilliant Ways Series 2, 105-108.

Fahdin, R. G. (2020). Student's perception toward the use of TikTok in learning English vocabulary. International Conference Labma Scientific Fair, 61-68.

Geddes, S. (2004). Mobile learning in the 21st century: Benefit for learners. Knowledge Tree, 6,13 .

Hamad, K. Q., \& Seyyedi, K. (2020). Communication challenges facing Soran University students in speaking English as a foreign language. International Journal of Linguistics, Literature and Translation (IJLLT), 3 (8), 40-53.

Handayani, A. D., Cahyono, B. Y., \& Widiati, U. (2018). The use of Instagram in the teaching of EFL writing: Effect on writing ability and students' perceptions. Studies in English Language Teaching, 6(2), 112. https://doi.org/10.22158/selt.v6n2p112

Hanim, S. (2021). Social media usage for learning English language. Randwick International of Education and Linguistics Science (RIELS) Journal, 2(3), 461-466.

Hashim, H., Yunus, M. M., Amin, E. M., Azwa, N., \& Ozir, M. (2017). Mobile-assisted Language Learning (MALL) for ESL learners: A review of affordances and constraints. Sains Humanika, 9, 1-5. https://doi.org/10.11113/SH.V9N1-5.1175

Iswahyuni, D. (2021). Embracing social media to improve ESL learners' English skill. Professional Journal of English Education, 4(4), 704-711.

Kacetl, J., \& Klímová, B. (2019). Use of smartphone applications in English language learningA challenge for foreign language education. Educational Sciences, 9(3), 1-9. https://doi:10.3390/educsci9030179

Keegan, D. (2002). The Future of Learning: From eLearning to mLearning. http://www.fernunihagen.de/ZIFF/mlearn.htm

Ketut, S. I., Bagus, M. A. P. I., Nyoman, T. A. I., \& Wayan, L. Y. I. (2019). The use of Google Classroom in the learning process. Journal of Physics: Conference Series, 1175(1), 012165. https://doi.org/10.1088/1742-6596/1175/1/012165

Koniah, S. K., Fitrianingsih, A., \& Rohmah, I. I. (2021). The phenomenon of students' responses toward the use of TikTok videos in learning simple present tense at Smk Al- Mustawa in Randublatung. Jurnal Pendidikan Edutama, 8(2), 1-6.

Kuimova, M., Burleigh, D., Uzunboylu, H., \& Bazhenov, R. (2018). Positive effects of mobile learning on foreign language learning. TEM Journal, 7(4), 837-841.

Lee, J. S. (2020). Informal digital learning of English and strategic competence for crosscultural communication: Perception of varieties of English as a mediator. ReCALL, 32(1), 47-62. https://doi.org/10.1017/S0958344019000181

Li, C., \& Lalani, F. (2020). The Covid-19 pandemic has changed education forever. This is how. World Economic Forum. https://www.weforum.org/agenda/2020/04/ coronaviruseducation-global-covid19-online-digital-learning/.

Mezied, S. K. (2021). The effect of random excitement strategy on developing English conversation skills among ninth graders. IUGJEPS, 92(4), 825-842.

Miangah, T. M., \& Nezarat, A. (2012). Mobile-assisted language learning. International Journal of Distributed and Parallel Systems, 3(1), 309. 
Nugroho, A., \& Rahmawati, A. (2020). Let's write a caption!: Utilizing Instagram to enhance ESP students' writing skills. Jurnal Basis, 7(1), 1. https://doi.org/10.33884/basisupb.v7i1.1782

Nuraeni, E. P. (2021). The use of Podcast to promote students' speaking ability in online learning at the Covid-19 pandemic. Journal of English Educational Study (JEES), 4(1), 11-20.

Nurullayevna, S. N. (2020). The key of effective communication is pronunciation. European Journal of Humanities and Educational Advancements (EJHEA), 1(4), 5-7.

Priya, M. L., \& Kumar, D. P. (2020). Teaching phonetics to enhance pronunciation in an ESL classroom. Journal of Critical Reviews, 7(2), 669-672.

Rahmawati, R., Drajati, N. A., \& Asib, A. (2019). A portrait of higher education students' experiences of doing informal digital learning of english (IDLE) speaking practices in Indonesia. English Education: Jurnal Tadris Bahasa Inggris, 12(2), 115-126. http://ejournal.radenintan.ac.id/index.php/ENGEDU/article/view/5428/3184

Rose, S., Badr, K., Fletcher, L., Paxman, T., Lord, P., Rutt, S., Styles, B., \& Twist, L. (2021). Impact of school closures and subsequent support strategies on attainment and socioemotional wellbeing in Key Stage 1. www.educationendowmentfoundation.org.uk

Sedliarova, O., \& Soloveva, N. (2021). Comics as educational tools in teaching English grammar, lexis and communication skills. Proceedings of the International Scientific Conference, $V, 615-627$.

Shadiev, R., Liu, T., \& Hwang, W. Y. (2019). Review of research on mobile-assisted language learning in familiar, authentic environments. British Journal of Educational Technology, 1-12. https://doi:10.1111/bjet.12839

Chen, S. (2020). Literacy for all: 2019 apps by worldwide downloads. https://tech.tgbus.com/news/65007

Sherin, M. G., \& Dyer, E. B. (2017). Teacher self-captured video: Learning to see. Phi Delta Kappan, 98(7), 49-54.

Short, D. (2017). How to integrate content and language learning effectively for English language learners. EURASIA Journal of Mathematics Science and Technology Education, 13(7b), 4237-4260.

Siau, K. (2018). Education in the age of artificial intelligence: How will technology shape learning? The Global Analyst, 7(3), 22-24.

Suthiwartnarueput, T., \& Wasanasomsithi, P. (2012). Effects of using Facebook as a medium for discussions of English grammar and writing of low-intermediate EFL students. Electronic Journal of Foreign Language Teaching, 9(2), 194-214. http://eflt.nus.edu.sg/

Syaifuddin, Abdi, W. M., Nabilah, A., Larassati, D., \& Lazuwardiyyah, F. (2021). Students' perception toward the use of TikTok video in learning writing descriptive text at MAN 1 Gresik. Journal of Research on English and Language Learning, 2, 16-21.

Tuyen, N. L. (2021). A study on difficulties and solutions in English speaking 3 Skills of students at Hufi. https://doi.org/10.31235/osf.io/e2bn9

United Nations. (2020). Goal 4: Quality education. The global goals. https://www.globalgoals.org/4-quality-education

Vygotsky, L. S. (1978). Mind in society. Harvard University Press.

Wahyuningsih, S., \& Afandi, M. (2020). Investigating English speaking problems: Implications for speaking curriculum development in Indonesia. European Journal of Educational Research, 9(3), 967-977. 


\section{DEVELOPMENT}

Vol. 11, No. 1, 2022, E-ISSN: 2226-6348 @ 2022 HRMARS

Wang, Y. (2009). Impact of Lev Vygotsky on special education. Canadian Social Science, 100104. https://doi.org/Academic OneFile.

Wong, L. H., King, R. B., Chai, C. S., and Liu, M. (2016). Seamlessly learning Chinese: Contextual meaning making and vocabulary growth in a seamless Chinese as a second language learning environment. Instructional Science, 44(5), 1-24.

Wongsa, M., \& Son, J. B. (2020). Enhancing Thai secondary school students' English speaking skills, attitudes and with drama-based activities and Facebook. Innovation in Language Learning and Teaching.

$\mathrm{Wu}$, L. (2020). Comparative analysis of video stories and user behaviors on WeChat and TikTok. Advances in Social Science, Education and Humanities Research, 496, 329-333.

Xie, X., Siau, K., \& Nah, F. F. H. (2020). COVID-19 pandemic-online education in the new normal and the next normal. Journal of Information Technology Case and Application Research, 22(3), 175-187. https://doi.org/10.1080/15228053.2020.1824884

Xiuwen, Z., \& Razali, A. B. (2021). An overview of the utilization of TikTok to improve oral English communication competence among EFL undergraduate students. Universal Journal of Educational Research, 9(7), 1439-1451. https://doi.org/10.13189/ujer.2021.090710

Yemer, M. B., Denku, C. Y., \& Berhanu, M. S. (2021). Social media usage in improving English language proficiency from the viewpoint of medical students. Advances in Medical Education and Practice, 12, 519-528.

Yunus, M. M., Zakaria, S., \& Suliman, A. (2019). The potential use of social media on Malaysian primary students to improve writing. International Journal of Education and Practice, 7(4), 450-458. 